\title{
Genetic (non)-homogeneity of the bracket fungi of the genus Ganoderma (Basidiomycota) in Central Europe
}

\section{Beck $T^{1}$, Gáperová $S^{1}$, Gáper $\mathrm{J}^{2,3}$, Náplavová $\mathrm{K}^{3}$, Šebesta $\mathrm{M}^{2}$, Kisková $\mathrm{J}^{4}$ and Pristaš $\mathbf{P}^{4}$}

\author{
${ }^{1}$ Matej Bel University, Faculty of Natural Sciences, Department of Biology and Ecology, Tajovského 40, 97401 Banská \\ Bystrica, Slovak Republic \\ ${ }^{2}$ Technical University in Zvolen, Faculty of Ecology and Environmental Sciences, Department of Biology and Ecology, \\ T. G. Masaryka 24, 96063 Zvolen, Slovak Republic \\ ${ }^{3}$ University of Ostrava, Faculty of Sciences, Department of Biology and Ecology, Chittussiho 10,71000 Ostrava, \\ Czech Republic \\ ${ }^{4}$ Pavol Jozef Šafárik University in Košice, Faculty of Natural Sciences, Institute of Biology and Ecology, Šrobárova 2, \\ 04154 Košice, Slovak Republic
}

Beck T, Gáperová S, Gáper J, Náplavová K, Šebesta M, Kisková J, Pristaš P 2020 - Genetic (non)homogeneity of the bracket fungi of the genus Ganoderma (Basidiomycota) in Central Europe. Mycosphere 11(1), 225-238, Doi 10.5943/mycosphere/11/1/3

\begin{abstract}
During systematic surveys of urban, rural and forest areas in Slovakia and Moravia (Czech Republic) and occasional botanical excursions in Northern Hungary, seventy-five collections of Ganoderma spp. were gathered during 2015 - 2018. Taxa identification was accomplished through observation of morphological characteristics of their mature, sporulating and undeformed basidiocarps. The genetic diversity of the collections was investigated by using internal transcribed spacer (ITS1/4) of ribosomal DNA sequences comparisons. Both analyses showed that the 75 collections clustered into six clades, namely, G. applanatum, G. adspersum, G. resinaceum, G. pfeifferi, G. lucidum and G. carnosum in accordance with the morphospecies concept.

The sequence comparison demonstrated genetic homogeneity of all $G$. resinaceum clade. Multiple sequence alignment indicated the presence of two $G$. resinaceum sequence types with significant statistic support and, probably, the existence of two cryptic taxa. The twenty-eight collections clustered with the $G$. applanatum group and the twenty other collections were grouped with morphologically very similar $G$. adspersum group. However, ITS sequences show no close similarity between these two species.
\end{abstract}

Key words - basidiospores - cryptic taxa - interspecific and intraspecific variations - ITS phylogeny - polypores - wood-decay

\section{Introduction}

Ganoderma (Ganodermataceae, Agaricomycetes, Basidiomycota) is a well-known white-rot wood-decay genus of bracket macrofungi (polypores) because of its medicinal properties (Bishop et al. 2015, Hapuarachchi et al. 2016) and phytopathological importance (Schwarze \& Ferner 2003, Ryvarden \& Melo 2014). The genus differs from other polypores by the crust-like upper surfaces of their basidiocarps, double-walled basidiospores with an enlarged or truncated apex and exosporium with ornamentations (Karsten 1881, Moncalvo 2000, Niemelä \& Miettinen 2008, Hennicke et al. 
2016, Costa-Rezende et al. 2017). The hyphal system is arboreal: the generative hyphae are hyaline, thin-walled, clamped; the arboriform hyphae are yellowish brown, thick-walled; basidiospores are (ellipsoid-, cylindric-) ovoid; cystidia absent (Breitenbach \& Kranzlin 1986, Gilbertson \& Ryvarden 1987, Hansen \& Knudsen 1997, Bernicchia 2005).

Ganoderma species were classified primarily on the basis of morphological features, such as an appearance of pileus surface (dull or laccate, resinous deposits), colour of the context, presence of the stipe, and shape, size and ornamentation of the basidiospores (Breitenbach \& Kranzlin 1986, Gilbertson \& Ryvarden 1987, Hansen \& Knudsen 1997, Bernicchia 2005, Torres-Torres \& Dávalos 2012, Ryvarden \& Melo 2014, Costa-Rezende et al. 2017). However, over the past three decades, there has been substantial progress in our understanding of genetic variability within these traditionally recognized wood-decay macrofungi. Molecular systematics has been shown to be a valuable tool in their current taxonomy (Papp 2019). The first fundamental works on phylogenetic studies of Ganoderma using the internal transcribed spacer (ITS) and large subunit (LSU) rDNA sequences are those of Moncalvo et al. (1994, 1995a, 1995b), Bae et al. (1995), Hseu et al. (1996), and Sokoł et al. (1999) in the 1990s. The second major advance work was in the late 2000's, when Guglielmo and co-workers carried out PCR assays with taxon-specific primers for the early diagnostics of the most important phytopathological species (Guglielmo et al. 2007, 2008, 2010). In molecular studies of Ganoderma, the most common sequenced marker is the ITS of nuclear DNA (e.g. Moncalvo 2000, Smith \& Sivasithamparam 2000, Moncalvo \& Buchanan 2008, Douanla-Meli \& Langer 2009, Cao et al. 2012, Park et al. 2012, Wang et al. 2012, Zhou et al. 2015, Hapuarachchi et al. 2019, Hennicke et al. 2016, Xing et al. 2016, 2018), which is one of the most preferred regions for genetic identification of fungi (Raja et al. 2017). ITS was accepted as the universal barcode marker for fungi by a consortium of mycologists (Schoch et al. 2012, Raja et al. 2017). In addition, many other markers have been used for phylogenetic studies within Ganoderma genus, such as nuclear large subunit ribosomal DNA (nrLSU, Costa-Rezende et al. 2017), mitochondrial small subunit ribosomal DNA (mtSSU) (Hong \& Jung 2004), protein coding genes: translation elongation factor 1- $\alpha$ (tef1- $\alpha$ ), RNA polymerase II largest subunit (RBP1), RNA polymerase II second largest subunit (RPB2), $\beta$-tubulin ( $\beta$-tub) and intergenic spacer region (IGS) (e.g. Cao et al. 2012, Park et al. 2012, Wang et al. 2012, Zhou et al. 2015, Costa-Rezende et al. 2017). Due to the development of molecular methods, many new species of Ganoderma are being described, e.g. Ganoderma ellipsoideum Hapuar., T.C. Wen \& K.D. Hyde, sp. nov. (Hapuarachchi et al. 2018) and Ganoderma casuarinicola J.H. Xing, B.K. Cui \& Y.C. Dai, sp. nov. (Xing et al. 2018).

Within Ganoderma, over 250 (up to 400) species have been described worldwide, most of them from the tropics (Moncalvo et al. 1995a, Richter et al. 2015). Only seven species naturally occur in Central Europe (Kotlaba 1984, Sokół 2000, Bernicchia 2005, Papp \& Szabó 2013, Ryvarden \& Melo 2014). Although many molecular studies have been conducted within the genus, especially within G. lucidum complex (e.g. Cao et al. 2012, Wang et al. 2012, Zhou et al. 2015), available data from Central Europe are rare. The aim of the present study, therefore, was to analyze both interspecific and intraspecific genetic variability in this genus using molecular methods based on our ITS sequences in accordance with the morphospecies concept from Central Europe.

\section{Materials \& Methods}

\section{Fungal Collections}

A total of seventy-five basidiocarps of Ganoderma spp. were collected in Central Europe. Most of the collections were acquired during systematic surveys of urban, rural and forest areas in Slovakia and Moravia (Czech Republic) and occasional botanical excursions in northern Hungary during 2015 - 2018. A schematic map illustrating their spatial distribution is given in Fig. 1.

The collections of the recorded species are also documented and voucher specimens are deposited in the Herbarium of the Department of Biology and Ecology, Faculty of Natural Sciences, Matej Bel University in Banská Bystrica, Slovakia. The specimens were morphologically identified by routine methods and determined according to standard, widely used keys (Breitenbach 
\& Kranzlin 1986, Gilbertson \& Ryvarden 1987, Hansen \& Knudsen 1997, Bernicchia 2005, Ryvarden \& Melo 2014). In order to observe basidiospores (without the outer wall and expanded vesicular apex), slide preparations mounted in $5 \% \mathrm{KOH}$ with cotton blue were drawn from dried tissue for each specimen and measured with maximum magnification (with immerse objective 100x) of a MOTIC light microscope (Motic Company, Germany). Thirty basidiospores from five basidiocarps of each species were measured for width and length of the inner wall. The nomenclature of fungi follows Index Fungorum (Cooper \& Kirk 2019).

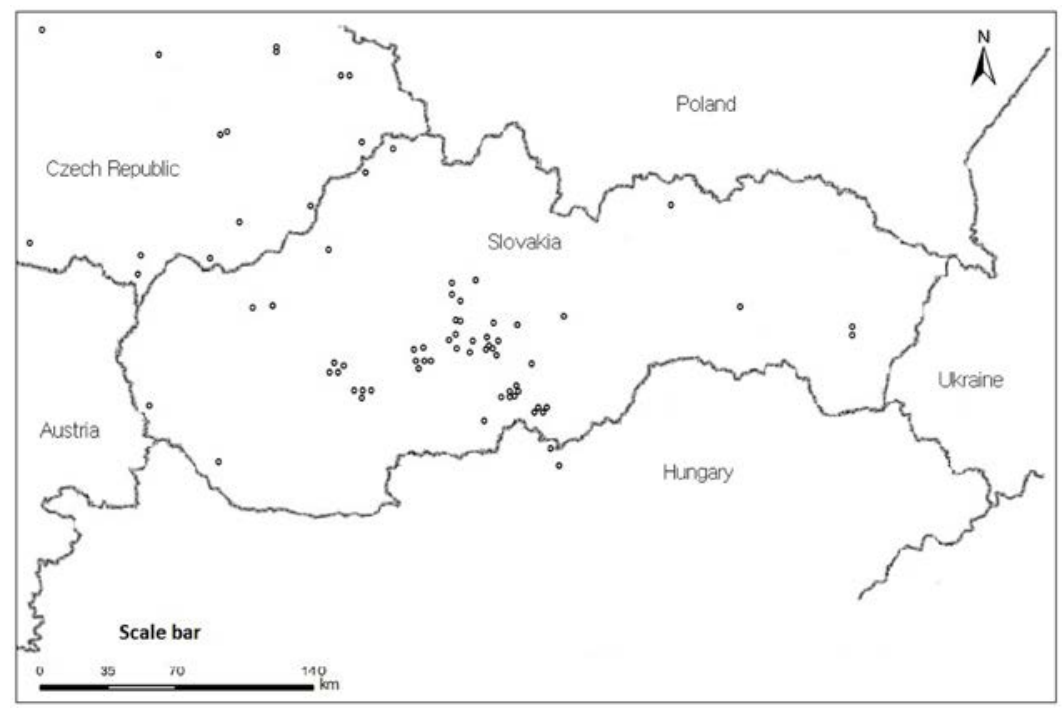

Figure 1 - Schematic map illustrating the spatial distribution of Ganoderma collections in Central Europe

\section{DNA Isolation}

Tissues from 75 fresh Ganoderma basidiocarps were ground using oscillating mill (MM200, Retsch GmbH, Haan, Germany). Total genomic DNA was extracted using the modified method described by Gašparcová et al. (2017). A small amount of fungal tissue (about $100 \mathrm{mg}$ ) was suspended in $300 \mu \mathrm{l}$ of lysis solution ( $2 \% \mathrm{w} / \mathrm{v}$ CTAB, $100 \mathrm{mM}$ Tris-HCl, $20 \mathrm{mM}$ EDTA, $1.4 \mathrm{M}$ $\mathrm{NaCl}, \mathrm{pH} 8.0)$ and heated 10 times in a microwave oven $(600 \mathrm{~W}$ for $4 \mathrm{~s})$. Then $300 \mu \mathrm{l}$ of fresh lysis solution was added again and the mixture was incubated at $100{ }^{\circ} \mathrm{C}$ for $2 \mathrm{~min}$. After that the mixture was extracted using $500 \mu \mathrm{l}$ chloroform and centrifuged for $3 \mathrm{~min}$. The purified upper aqueous phase was transferred to a new microcentrifuge tube. Extraction using chloroform was repeated once more. Then DNA was precipitated with 0.7 vol. of isopropyl alcohol. Then samples were centrifuged for $10 \mathrm{~min}$ at maximum speed $(12000 \mathrm{~g})$. The obtained DNA pellet was washed in $1 \mathrm{ml}$ of $70 \%$ ethanol, centrifuged for $5 \mathrm{~min}$ at $12000 \mathrm{~g}$, and dissolved in $50 \mu \mathrm{l}$ of PCR Grade Water (Solis BioDyne, Tartu, Estonia).

\section{PCR amplification and Sanger Sequencing}

The nuclear ribosomal ITS region was amplified with the primers ITS1 (TCC GTA GGT GAA CCT GCG G) and ITS4 (TCC TCC GCT TAT TGA TAT GC) according to White et al. (1990). The polymerase chain reaction (PCR) was performed in a T100TM Thermal Cycler (Biorad Laboratories, Inc., Singapore). PCR reaction mixture $(50 \mu \mathrm{l})$ contained $10 \mu \mathrm{l}$ of $5 \mathrm{x}$ HOT FIREpol ${ }^{\circledR}$ Blend Master Mix with $10 \mathrm{mM} \mathrm{MgCl}_{2}$ (Solis BioDyne, Tartu, Estonia), $1 \mu$ of each primer (10 pmol/ $\mu \mathrm{l}), 37 \mu \mathrm{l}$ of PCR Grade Water (Solis BioDyne, Tartu, Estonia) and $1 \mu \mathrm{l}$ of diluted genomic DNA (50 ng). Conditions of PCR cycling: an initial denaturation for 5 min at $94{ }^{\circ} \mathrm{C}$, followed by 35 cycles at $94{ }^{\circ} \mathrm{C}$ for $30 \mathrm{~s}, 45 \mathrm{~s}$ at $52{ }^{\circ} \mathrm{C}$ and $45 \mathrm{~s}$ at $72{ }^{\circ} \mathrm{C}$, a final extension at $72{ }^{\circ} \mathrm{C}$ for $10 \mathrm{~min}$. Then PCR products were visualized after electrophoresis on $1.5 \%$ agarose gel, purified using ExoSAP-IT (Affymetrix, Inc., Cleveland, Ohio, USA) according to the manufacturer's 
instructions, then sequenced in both directions using the same primers as for PCR at SEQme s.r.o. sequencing service (Dobřrišs, Czech Republic).

\section{Phylogenetic analyses}

About 600 bp ITS region was sequenced from all studied basidiocarps. In total, 75 ITS sequences were generated during this study and deposited in the GenBank database. The sequences from both primers were assembled using DNA Baser software (Heracle Biosoft, Romania) and resulted sequences were submitted to the GenBank database (For the list of GenBank accession numbers see Table 1). For phylogenetic analyses, sequences obtained were aligned using the clustalw algorithm and the phylogenetic tree was constructed using the Neighbor-Joining method. The reliability of the estimated phylogenetic tree was evaluated using bootstrapping with 1000 repetitions. For all phylogenetic analyses, MEGA software version 7 was used (Kumar et al. 2016). As many Ganoderma entries in the GenBank are misidentified or lack some important details (e.g. host species or locality), the sequences obtained during this study were used for the molecular analyses. The data obtained (alignment and tree file) were deposited to the Treebase database (Submission ID: 24333). For sequence comparisons, blastn analysis (Altschul et al. 1990) was performed against the GenBank database (Benson et al. 2013).

\section{Results}

The species/specimens recognized in the study, their geographical locations in Central Europe and their hosts are given in Table 1.

Table 1 GenBank accessions numbers of the 75 specimens of Ganoderma spp. used in this study.

\begin{tabular}{llll}
\hline Species/specimens No. & Geographical origin & Host & GenBank accession No. \\
\hline Ganoderma applanatum & & & \\
JTGA & Slovakia & Fagus sylvatica & MK415277 \\
FS8G & Slovakia & Fagus sylvatica & MK415253 \\
MS115 & Slovakia & Tilia sp. & MK415297 \\
3GL & Czech Republic & unknown & MK415242 \\
MS116 & Slovakia & Tilia sp. & MK415298 \\
MS117 & Slovakia & Tilia sp. & MK415299 \\
CA09ND & Slovakia & unknown & MK415248 \\
BBURP5 & Slovakia & unknown & MK415247 \\
G171 & Slovakia & Quercus robur & MK415260 \\
K63 & Czech Republic & unknown & MK415284 \\
K60 & Czech Republic & unknown & MK415283 \\
K15 & Czech Republic & unknown & MK415278 \\
BB010ND & Slovakia & unknown & MK415245 \\
BBURP1 & Slovakia & unknown & MK415246 \\
DT211 & Slovakia & Fraxinus excelsior & MK415251 \\
K28 & Czech Republic & Populus sp. & MK415279 \\
K33 & Czech Republic & Alnus sp. & MK415281 \\
DT212 & Slovakia & Fraxinus excelsior & MK415252 \\
K36 & Czech Republic & unknown & MK415282 \\
B47 & Czech Republic & Fagus sylvatica & MK415243 \\
G2 & Slovakia & Populus tremula & MK415264 \\
D3 & Slovakia & Fagus sylvatica & MK415249 \\
G012 & Slovakia & Quercus sp. & MK415254 \\
G013 & Slovakia & unknown & MK415255 \\
GVF & Slovakia & Fagus sylvatica & MK415275 \\
GNRT & Slovakia & Tilia sp. & MK415273 \\
VaG & Czech Republic & Acer pseudoplatanus & MK415313 \\
MS15 & Slovakia & Fagus sylvatica & MK415308 \\
\hline Ganoderma resinaceum & & & \\
Type A & & Fraxinus excelsior & MK415304 \\
MS131 & Slovakia & Fraxinus excelsior & MK415305 \\
MS133 & Slovakia & &
\end{tabular}


Table 1 Continued.

\begin{tabular}{|c|c|c|c|}
\hline Species/specimens No. & Geographical origin & Host & GenBank accession No. \\
\hline GSP & Slovakia & Quercus sp. & MK415274 \\
\hline \multicolumn{4}{|l|}{ Type B } \\
\hline MS8 & Slovakia & Gleditschia triacanthos & MK415309 \\
\hline $14 \mathrm{~b}$ & Slovakia & Negundo aceroides & MK415241 \\
\hline SADS1 & Slovakia & Salix alba & MK415311 \\
\hline \multicolumn{4}{|l|}{ Ganoderma lucidum } \\
\hline GL4 & Slovakia & unknown & MK415270 \\
\hline K87 & Czech Republic & unknown & MK415286 \\
\hline K84 & Czech Republic & Quercus sp. & MK415285 \\
\hline GL5 & Slovakia & Quercus sp. & MK415271 \\
\hline GLP & Slovakia & unknown & MK415272 \\
\hline GL & Slovakia & Quercus sp. & MK415269 \\
\hline \multicolumn{4}{|l|}{ Ganoderma carnosum } \\
\hline GCAND & Czech Republic & unknown & MK415267 \\
\hline G177 & Slovakia & unknown & MK415261 \\
\hline BB001ND & Slovakia & unknown & MK415244 \\
\hline GVZV & Slovakia & Larix decidua & MK415276 \\
\hline K91 & Czech Republic & Picea abies & MK415287 \\
\hline ZV012PN & Slovakia & Pinus nigra & MK415314 \\
\hline GC011ND & Slovakia & unknown & MK415266 \\
\hline SG4 & Slovakia & Picea sp. & MK415312 \\
\hline \multicolumn{4}{|l|}{ Ganoderma pfeifferi } \\
\hline M2 & Slovakia & Tilia platyphyllos & MK415295 \\
\hline MS10 & Hungary & Quercus robur & MK415296 \\
\hline G16T & Slovakia & Fagus sylvatica & MK415259 \\
\hline G15T & Slovakia & Fagus sylvatica & MK415258 \\
\hline G1ZH & Slovakia & Acer platanoides & MK415263 \\
\hline PMS13 & Slovakia & Fagus sylvatica & MK415310 \\
\hline LeG1 & Czech Republic & Fagus sylvatica & MK415290 \\
\hline \multicolumn{4}{|l|}{ Ganoderma adspersum } \\
\hline LV1 & Slovakia & Aesculus hippocastanum & MK415291 \\
\hline G1 & Slovakia & Quercus sp. & MK415256 \\
\hline G13 & Slovakia & Tilia cordata & MK415257 \\
\hline GDS & Slovakia & Fraxinus excelsior & MK415268 \\
\hline ZV17 & Slovakia & unknown & MK415315 \\
\hline K29 & Czech Republic & unknown & MK415280 \\
\hline LC7 & Slovakia & Tilia cordata & MK415289 \\
\hline LC013TC & Slovakia & Tilia cordata & MK415288 \\
\hline LVC4 & Slovakia & unknown & MK415293 \\
\hline G2ZH & Slovakia & Tilia platyphyllos & MK415265 \\
\hline MS137 & Slovakia & Quercus petraea & MK415306 \\
\hline DT210 & Slovakia & unknown & MK415250 \\
\hline MS125 & Slovakia & Fraxinus excelsior & MK415302 \\
\hline LVC5 & Slovakia & Tilia platyphyllos & MK415294 \\
\hline LV2 & Slovakia & Aesculus hippocastanum & MK415292 \\
\hline MS124 & Slovakia & Fraxinus excelsior & MK415301 \\
\hline MS126 & Slovakia & Fraxinus excelsior & MK415303 \\
\hline MS143 & Slovakia & Acer sp. & MK415307 \\
\hline G1TT & Slovakia & Tilia cordata & MK415262 \\
\hline MS120 & Slovakia & unknown & MK415300 \\
\hline
\end{tabular}

Species determination through observation of morphological features of their mature, sporulating and undeformed basidiocarps showed that the 75 Ganoderma collections in Central Europe divided into six morphospecies: G. applanatum (Pers.) Pat., G. adspersum (Schulzer) Donk, G. resinaceum Boud., G. pfeifferi Bres., G. lucidum (Curtis) P. Karst., and G. carnosum Pat. G. valesiacum Boud., the seventh known, extremely rare European species, was not recorded and, therefore, it is not included in this study. The ITS sequences comparisons confirmed the existence 
of 6 statistically well supported clades in concordance with the morphological identification (Fig. 2), however different levels of intra- and inter-clades variabilities were observed (Tables 2, 3).

The largest group of basidiocarps was identified in G. applanatum. The clade G. applanatum included 28 isolates from Slovakia and Czech Republic, most commonly occurring on stumps of unknown trees or Fagus sylvatica L. No intra-species genetic variability was observed in this clade (Table 3) and sequence comparisons indicated that sequences obtained in our study are identical to the G. applanatum sequences retrieved from GenBank, e.g. strain 407 from Poland (MH320562), strain CBS 187.31 from Germany (MH855178), strain 7411 from China (MG279158).

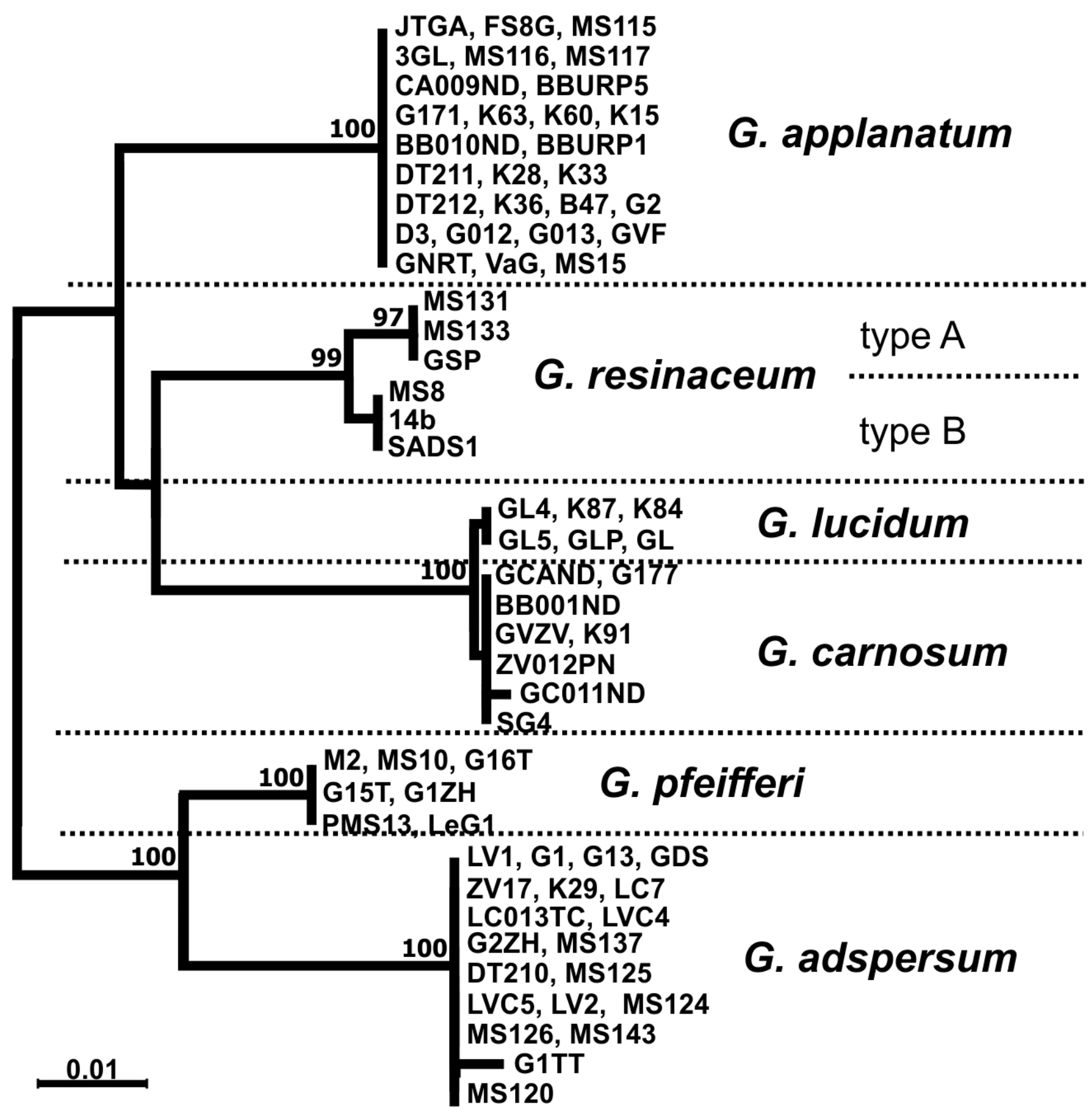

Figure 2 - Unrooted phylogenetic tree documenting the relatedness among Central European collections of Ganoderma spp. The tree was inferred using the Neighbor-Joining method, the evolutionary distances were computed using the Kimura 2-parameter method and are in the units of the number of base substitutions per site. Numbers at nodes shown the percentage of replicate trees in which the associated taxa clustered together in the bootstrap test after 1000 repetitions. 
Table 2 The evolutionary divergences between groups of Ganoderma spp. from Central Europe based on ITS sequence comparisons. The number of base differences per sequence from averaging over all sequence pairs between groups are shown.

\begin{tabular}{|c|c|c|c|c|c|c|c|}
\hline & 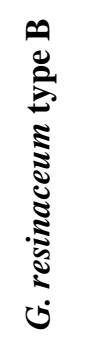 & 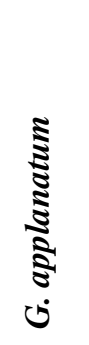 & 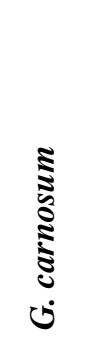 & 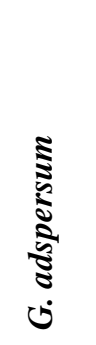 & 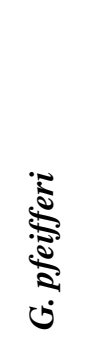 & 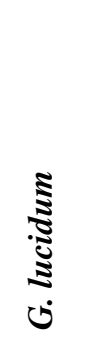 & 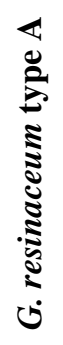 \\
\hline G. resinaceum type B & 0.0 & & & & & & \\
\hline G. applanatum & 21.0 & 0.0 & & & & & \\
\hline G. carnosum & 23.1 & 25.1 & 0.0 & & & & \\
\hline G. adspersum & 31.1 & 33.1 & 36.2 & 0.0 & & & \\
\hline G. pfeifferi & 28.0 & 27.0 & 34.1 & 17.1 & 0.0 & & \\
\hline G. lucidum & 23.8 & 25.8 & 0.9 & 35.4 & 33.3 & 0.0 & \\
\hline G. resinaceum type A & 4.0 & 23.0 & 23.1 & 32.1 & 28.0 & 23.8 & 0.0 \\
\hline
\end{tabular}

Table 3 The average evolutionary divergence within groups of Ganoderma spp. from Central Europe based on ITS sequence comparisons. The number of base differences per sequence from averaging over all sequence pairs within each group are shown.

\begin{tabular}{|c|c|c|c|c|c|c|c|}
\hline & 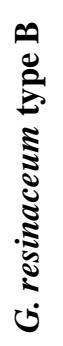 & 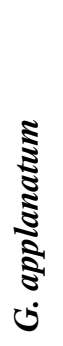 & 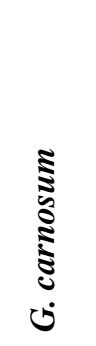 & 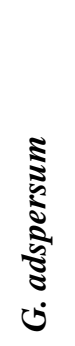 & $\frac{\underbrace{\frac{a}{2}}_{0}}{\frac{2}{2}}$ & $\underset{ن}{\mathfrak{\Xi}}$ & 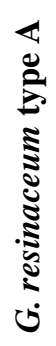 \\
\hline \multicolumn{8}{|l|}{ The Number of Base } \\
\hline $\begin{array}{l}\text { Differences within the } \\
\text { Group }\end{array}$ & 0 & 0 & 0.25 & 0.2 & 0 & 0.429 & 0 \\
\hline
\end{tabular}

The second largest clade consists of 19 isolates from Slovakia and 1 from Czech Republic and was classified as $G$. adspersum species. The isolates showed very low intra-species genetic variability (Table 3) and sequences obtained were practically identical to the ITS sequences of $G$. adspersum isolates Dai 13191 isolate from China, 4137 isolate from Belgium, or JV 1106/7 isolate from USA (MG279153, MG066632, and KF605651 respectively). The G. adspersum group is morphologically very similar to more common G. applanatum group. Specimens in both groups had sessile basidiocarps and were attached directly to the stump or tree's trunk with no stipe. However, ITS sequences showed that the two groups are phylogenetically well separated and, therefore, these molecular methods have been useful for species delimitation. The basidiospores of the two groups had also different sizes $(\mu \mathrm{m})$ : $8.4-11.0 \times 6.0-8.4$ for basidiocarps of $G$. adspersum and $6.0-10.0 \times 4.5-6.5$ for G. applanatum (Table 4).

To the $G$. resinaceum clade six isolates were classified. However phylogenetic analysis identified significant genetic diversity within this clade. Two types of sequences were identified, marked as type A and type B in Fig. 2. Type A includes isolates MS131, MS133 and GSP, and type B includes isolates MS8, 14b and SADS1 (Fig. 2). Isolates of type A were recorded on Fraxinus 
excelsior L. and Quercus sp., isolates of type B on Gleditschia triacanthos L., Negundo aceroides Moench and Salix alba L. While no inter-type variability was observed (Table 3), the two types of sequences differ by 4 nucleotides in ITS2 region (Table 2) indicating possible genetic nonhomogeneity of the species and the existence at least two cryptic species within $G$. resinaceum. The non-homogeneity of $G$. resinaceum is probably widely occurred as the blastn analysis confirmed that both types of sequences already have been reported. E.g. sequences identical to the $G$. resinaceum type A sequences were reported for isolate 7 from Poland (KY196415) or CBS 747.84 isolate from Korea (JQ520198). The sequences identical to the G. resinaceum type B sequences were reported for DP2 isolate from Celtis australis L. in Italy (AM906060) or for F-1 isolate from France (JN588588). The differences between type A and type B isolates were accompanied by the differences in morphology and spore size. The basidiocarps of type A were sessile with no stipes, and basidiospore size of $9.6-14.4 \times 6.0-8.4 \mu \mathrm{m}$. Type B specimens had sessile basidiocarps with or without stipes and basidiospore size of $9.6-12.0 \times 7.2-9.6 \mu \mathrm{m}$. In addition, the length to width ratio of type A basidiospores was 1.7 and type B 1.34 (Table 4). The observed genetic differences between two types of $G$. resinaceum sequences were found to be 4 times higher than those for generally accepted and validly described G. lucidum and G. carnosum species (Table 2).

The G. lucidum clade consists of six isolates from Quercus sp. or unidentified trunks of probably broadleaf trees. The isolates showed limited intra-species variability (Table 3) and sequence comparison showed complete identity to the other G. lucidum sequences in the GenBank e.g. to MS183CA isolate from California, USA (MG911000) or to ZBS1 isolate from Russia (MF419230). The G. lucidum specimens had basidiospores of size $8.0-10.5 \times 5.5-7.0 \mu \mathrm{m}$ (Table 4).

To the G. carnosum clade eight isolates growing on coniferous trees Larix decidua Mill., Picea abies (L.) H. Karst., Picea sp. and Pinus nigra Arn. were classified. The isolates showed very limited genetic diversity and sequence comparison showed complete identity to the other $G$. carnosum sequences in the GenBank database e.g. to JV $1208 / 10 \mathrm{KN}$ isolate from USA (KF605626). The G. carnosum specimens had basidiospores of size $9.0-12.0 \times 6.0-8.5 \mu \mathrm{m}$ (Table 4).

Surprisingly very low genetic diversity was observed between G. lucidum and G. carnosum clades (Table 2). Despite the strong statistic support, (bootstrap value 100, see Fig. 2), the clades differ in general by a single nucleotide polymorphism questioning the validity of these taxa. Specimens in both clades were morphologically very similar: basidiocarps with stipe and very similar basidiospores, but basidiospores of G. carnosum were longer and wider (Table 4). They also differed in the colour of the basidiocarp surface ( $G$. lucidum has lighter) and host preferences.

The G. pfeifferi clade consists of seven isolates from Slovakia, Czech Republic and Hungary. Basidiocarps grew on four species of hardwoods, mainly on F. sylvatica. ITS sequences of these isolates did not show intra-species genetic variability (Table 3) and were identical to the ITS sequences of e.g. Dai 12153 isolate from China, JV 0511/11 isolate from USA, or GPF2 isolate from Poland (MG279164, KF605660, and JN00887 respectively). The G. pfeifferi had basidiospores of size $9.5-14.4 \times 7.0-10.0 \mu \mathrm{m}$. The length to width ratio of basidiospores was similar to $G$. resinaceum type B, 1.33. These two groups of Ganoderma basidiocarps had the widest spores among all studied species (Table 4).

Table 4 Basidiospores of Central European isolates of Ganoderma analysed in this study.

\begin{tabular}{|c|c|c|}
\hline Species (Type) Code & Length (Min - Max) × Width (Min - Max) Mm & $\begin{array}{l}\text { Length to Width Ratio } \\
\text { (Average Value) }\end{array}$ \\
\hline Ganoderma adspersum & $8.4-11.0 \times 6.0-8.4$ & 1.50 \\
\hline DT210 & $9.0-11.0 \times 6.0-7.5$ & 1.53 \\
\hline LV2 & $9.0-11.0 \times 6.0-7.5$ & 1.47 \\
\hline ZV17 & $9.6-10.8 \times 6.0-8.4$ & 1.56 \\
\hline LC013TC & $9.6-10.8 \times 6.0-8.4$ & 1.56 \\
\hline G13 & $8.4-10.8 \times 6.0-8.4$ & 1.39 \\
\hline
\end{tabular}


Table 4 Continued.

\begin{tabular}{|c|c|c|}
\hline Species (Type) Code & Length (Min - Max) × Width (Min - Max) Mm & $\begin{array}{l}\text { Length to Width Ratio } \\
\text { (Average Value) }\end{array}$ \\
\hline Ganoderma applanatum & $6.0-10.0 \times 4.5-6.5$ & 1.50 \\
\hline FS8G & $8.0-10.0 \times 5.0-6.5$ & 1.57 \\
\hline BURP1 & $8.0-9.5 \times 5.0-6.0$ & 1.51 \\
\hline GNRT & $7.0-10.0 \times 4.5-6.5$ & 1.52 \\
\hline G013 & $7.0-8.0 \times 5.0-5.5$ & 1.51 \\
\hline GVF & $6.0-9.6 \times 4.8-6.0$ & 1.45 \\
\hline Ganoderma carnosum & $9.0-12.0 \times 6.0-8.5$ & 1.42 \\
\hline G177 & $9.6-12.0 \times 7.2-8.4$ & 1.36 \\
\hline GC011ND & $9.0-11.0 \times 6.0-7.5$ & 1.43 \\
\hline GCAND & $10.8-12.0 \times 7.2-8.4$ & 1.43 \\
\hline GVZV & $9.0-11.0 \times 6.5-8.5$ & 1.40 \\
\hline K91 & $9.0-11.0 \times 6.0-8.0$ & 1.50 \\
\hline Ganoderma lucidum & $8.0-10.5 \times 5.5-7.0$ & 1.50 \\
\hline GL & $8.5-10.5 \times 5.5-7.0$ & 1.48 \\
\hline GLP & $8.5-10.0 \times 6.0-7.0$ & 1.48 \\
\hline K84 & $8.0-10.0 \times 6.0-7.0$ & 1.46 \\
\hline K87 & $9.0-10.0 \times 6.0-6.5$ & 1.53 \\
\hline GL4 & $8.0-10.0 \times 5.5-6.0$ & 1.57 \\
\hline Ganoderma pfeifferi & $9.5-14.4 \times 7.0-10.0$ & 1.33 \\
\hline MŠ10 & $12.0-14.4 \times 8.4-9.6$ & 1.43 \\
\hline PMS13 & $10.0-11.0 \times 7.0-8.0$ & 1.41 \\
\hline LeG1 & $10.0-14.0 \times 8.0-10.0$ & 1.23 \\
\hline M2 & $10.0-11.0 \times 7.0-9.0$ & 1.29 \\
\hline G15T & $9.5-11.0 \times 7.0-8.5$ & 1.27 \\
\hline $\begin{array}{l}\text { Ganoderma resinaceum } \\
\text { Type A }\end{array}$ & $9.6-14.4 \times 6.0-8.4$ & 1.70 \\
\hline MS131 & $9.6-14.4 \times 6.0-8.4$ & 1.75 \\
\hline MS133 & $10.0-12.5 \times 6.5-7.0$ & 1.66 \\
\hline GSP & $10.0-12.5 \times 6.5-7.5$ & 1.70 \\
\hline $\begin{array}{l}\text { Ganoderma resinaceum } \\
\text { Type B }\end{array}$ & $9.6-12.0 \times 7.2-9.6$ & 1.34 \\
\hline MS8 & $9.6-12.0 \times 7.2-9.6$ & 1.31 \\
\hline SADS1 & $10.0-12.0 \times 8.0-9.0$ & 1.36 \\
\hline
\end{tabular}

\section{Discussion}

A combination of morphological and molecular methods was used to analyze the diversity of Ganoderma spp. in Central Europe region. From this territory, seven species were reported previously (Kotlaba 1984, Sokół 2000, Gáperová 2001, Papp \& Szabó 2013, Ryvarden \& Melo 2014). In this study, among the collection of 75 basidiocarps collected during 2015 - 2018 years, six Ganoderma species were recorded with the dominance of G. applanatum and G. adspersum. The G. valesiacum species was not recorded. This species belongs to the G. lucidum complex, however, G. lucidum and G. valesiacum taxa could be conspecific (Ryvarden \& Gilbertson 1993, Ryvarden \& Melo 2014, Hapuarachchi et al. 2015). According to literature, G. valesiacum differs only by the length of the stipe (shorter than G. lucidum or rudimentary), the cracked crust of pileus, white context and host preference of Larix (Sokół 2000, Ryvarden \& Melo 2014). From Central Europe territory, there is a very limited number of G. valesiacum specimens and it is commonly found in natural coniferous forests at higher altitudes, mainly from the Alps (Plank \& Wolkinger 1981, Kotlaba 1984, Sokół 2000, Bernicchia 2005).

Ganoderma adspersum is very similar to the widespread $G$. applanatum. Both species can be distinguished by the size of their basidiospores; in G. adspersum: they are somewhat longer and larger. In addition, older tube layers are not whitening in its basidiocarps (Breitenbach \& Kränzlin 1986, Ryvarden \& Gilbertson 1993, Bernicchia 2005). In many cases, the combination of 
morphological and anatomical criteria of the basidiocarps and isolates, alone, however, may still not be sufficient, and the two species can often be confused (Peterson 1987, Leonard 1998, Moncalvo 2000). Our ITS sequences show, no close similarity for these species and, therefore, these molecular methods have been useful for their delimitation. This has been suggested by Moncalvo (2000) and Vlasák (2015) and subsequently confirmed by Guglielmo et al. (2008) and De Simone \& Annesi (2012) based mainly on the analysis of the Italian G. adspersum isolates and the G. applanatum isolates originating from other parts of the Europe. Similarly, Badalyan et al. (2012) confirmed this similarity between sequences generated outside the Europe based on the analysis of the Armenian G. adspersum isolates. While no intra-species genetic differences were observed in G. applanatum, very low diversity was detected in G. adspersum. G. pfeifferi can be easily distinguished in the field by its very dark context and thick, cracked and wrinkled resinouswaxy layer covering the pileus surface, especially from older basidiocarps of both G. lucidum and G. resinaceum. Similar to G. applanatum no intra-species genetic differences were observed in this species.

G. lucidum complex consists of three central European species namely, G. lucidum, G. carnosum, and G. resinaceum. Recent molecular studies have revealed that the commercially cultivated 'G. lucidum' (reishi or "Lingzhi”) = G. linghzi in East Asia is a different species from G. lucidum s. str. Ganoderma linghzi in East Asia now represents several non-European species, such as G. lingzhi, G. sichuanense, and G. multipileum, whereas G. lucidum s. str. only occurs in Europe and some parts of China (Moncalvo et al. 1995b, Cao et al. 2012, Hennicke et al. 2016, Papp et al. 2017, Loyd et al. 2018). Ganoderma carnosum and G. lucidum s. str. are also very similar in their early stages of basidiocarp development, and the two species are not easy to distinguish from each other based on morphological and anatomical criteria of basidiocarps. Our ITS sequences show, however, a close similarity of these species and the only criterion for dividing them seems to be the host preferences. Moreover, there are two kinds of sexual spores with a different size: smaller, thinwalled basidiospores termed "proterospores", which are ready to germinate at the beginning of the sporulation period, and larger, double-walled normal basidiospores, which are hard to germinate (Nuss 1982). In our study, however, no "proterospores" were recorded. In accordance with Ryvarden \& Melo (2014), we conclude that the mature G. carnosum basidiocarps have dark brown to black upper surface and larger normal basidiospores, while the G. lucidum basidiocarps have orange red to bay upper surface and smaller normal basidiospores. In the phylogenetic analysis, based on ITS and partial transcription elongation factor 1- $\alpha$ sequences data G. lucidum groups together with G. carnosum (Xing et al. 2016).

The $G$. resinaceum group is distinguished in the field by thick, soft and pale context. As we mentioned above, G. resinaceum basidiocarps of type B also can form a stipe. There is only one such finding in our study in a very wet area. These $G$. resinaceum basidiocarps may appear very similar to those of $G$. lucidum. But $G$. resinaceum has finely punctulate basidiospores whereas $G$. lucidum has coarse, rough basidiospore ornamentation (Steyaert 1972). We partially agree with the opinion of Kotlaba \& Pouzar (2009) that the basidiospore ornamentation is the only reliable feature between these two species in the above mentioned cases. Ganoderma lucidum basidiospores are shorter than those of $G$. resinaceum (both types).

As mentioned above, ITS was adopted as the universal barcode marker for fungi. ITS is the fastest evolving region of the nuclear ribosomal RNA cistron, it shows the highest genetic variation making it suitable for species-level identification (Raja et al. 2017). Moreover, it is successfully amplified by PCR and therefore is widely used (Schoch et al. 2012). Some authors (e.g. Cao \& Yuan 2013, Hapuarachchi et al. 2018) have described new species of Ganoderma spp. based only on ITS sequences. However, if the studied taxa show low interspecific variability for ITS (our G. lucidum and G. carnosum isolates), secondary markers should be used to accurately clarify their genetic diversity (Schoch et al. 2012). On the other hand, higher variability can be observed among the sequences within one valid species (2 genotypes of $G$. resinaceum). In such cases, sequencing of protein-coding genes is also recommended. These genes sometimes evolve faster than ITS and thus exhibit a higher degree of variability. The translation elongation factor $1-\alpha$ is one of the most 
commonly used protein-coding gene in the mycology (Raja et al. 2017). Also, Pristaš et al. (2013) found that tef-1 $\alpha$ sequences of two genotypes of wood-decay polypore Fomes fomentarius show a higher degree of variability and discriminatory power compared to ITS (Pristaš et al. 2013). The tef- $1 \alpha$ marker has also been used to study the genetic variability of Ganoderma spp. (Xing et al. 2016, 2018, Elliott et al. 2018). However, there is limited number of sequences available in the GenBank database compared to the frequently sequenced ITS region.

\section{Conclusions}

Seventy-five Ganoderma basidiocarps were separated into six clades based on morphology and phylogenetic analysis of ITS sequences: Ganoderma applanatum, G. adspersum, G. resinaceum, G. pfeifferi, G. lucidum, G. carnosum. No intra-species genetic differences observed in G. applanatum and G. pfeifferi and very low variation observed in G. adspersum. ITS sequences showed no close similarity for morphologically similar taxa G. applanatum and G. adspersum. Significant intra-species genetic diversity was observed in $G$. resinaceum clade. It was four times higher than the inter-species variability between valid species G. lucidum and G. carnosum. In G. resinaceum clade, two types of spores were identified, named as type $\mathrm{A}$ and $\mathrm{B}$, based on the size and shape of the spores. Further studies are needed to clarify the genetic variability within the clade G. resinaceum and between the clades G. carnosum and G. lucidum.

\section{Acknowledgements}

This work has been supported by grants from the Grant Agencies of the Ministry of Education, Science, Research and Sport of the Slovak Republic (VEGA No. 1/0286/17 and KEGA No. 025UMB-4/2017), from the Faculty of Science of the University of Ostrava (Czech Republic) SGS No. 10/PřF/2019, and ITMS Research \& Development Operational Programme; ERDF, Grant/Award Number: 26210120024.

\section{References}

Altschul SF, Gish W, Miller W, Myers EW et al. 1990 - Basic local alignment search tool. Journal of Molecular Biology 215, 403-410.

Badalyan S, Gharibyan N, Lotti M, Zambonelli A. 2012 - Morphological and genetic characteristics of collections of Ganoderma P. Karst. species. In: Zhang J, Wang H, Chen M (eds) Proceedings of the 18th Congress of the International Society for Mushroom Science. China Agriculture Press, Beijing, 247-254.

Bae SC, Lee SW, Kim HJ, Park DS et al. 1995 - PCR amplification of ITS II region of rDNA for the classification of Ganoderma spp. RDA Journal of Agricultural Science 37, 182-188.

Benson DA, Cavanaugh M, Clark K, Karsch-Mizrachi I et al. 2013 - GenBank. Nucleic Acids Research 41 (Database issue), D36-42.

Bernicchia A. 2005 - Polyporaceae s.l., Fungi Europaei. Massimo Candusso, Alassio.

Bishop KS, Kao CHHJ, Xu Y, Glucina MP et al. 2015 - From 2000 years of Ganoderma lucidum to recent developments in nutraceuticals. Phytochemistry 114, 56-65.

Breitenbach J, Kranzlin F. 1986 - Fungi of Switzerland, Non gilled fungi, 2nd edn. Mykologia Verlag, Lucerne.

Cao Y, Wu SH, Dai YCH. 2012 - Species clarification of the prize medicinal Ganoderma mushroom "Lingzhi”. Fungal Diversity 56, 49-62.

Cao Y, Yuan HS. 2013 - Ganoderma mutabile sp. nov. from southwestern China based on morphological and molecular data. Mycological Progress 12, 121-126.

Cooper J, Kirk P. 2019 - CABI Bioscience Database, Landscape Research, Index Fungorum Database. http://www.speciesfungorum.org/Names/Names.asp (accessed 05 February 2019).

Costa-Rezende DH, Robledo GL, Góes-Neto A, Reck MA et al. 2017 - Morphological reassessment and molecular phylogenetic analyses of Amauroderma s.lat. raised new 
perspectives in the generic classification of the Ganodermataceae family. Persoonia 39, 254269.

De Simone D, Annesi T. 2012 - Occurrence of Ganoderma adspersum on Pinus pinea. Phytopathologia Mediterranea 51, 374-382.

Douanla-Meli C, Langer E. 2009 - Ganoderma carocalcareus sp. nov., with crumbly-friable context parasite to saprobe on Anthocleista nobilis and its phylogenetic relationship in $G$. resinaceum group. Mycological Progress 8, 145-155.

Elliott ML, Des Jardin EA, Ortiz JV, Macias T. 2018 - Genetic variability of Ganoderma zonatum infecting palms in Florida. Mycologia 110, 339-346.

Gáperová S. 2001 - Synanthropic species in the genus Ganoderma. Acta Facultatis Ecologiae 8, 93-98.

Gašparcová T, Gáper J, Pristaš P, Kvasnová S et al. 2017 - Comparison of ITS-PCR-RFLP and MALDI-TOF MS methods for the identification of wood-decaying fungi of the genus Ganoderma. Chemické listy 111, 388-391.

Gilbertson RL, Ryvarden L. 1987 - North American polypores, 2nd edn. Fungiflora, Oslo.

Guglielmo F, Bergemann SE, Gonthier P, Nicolotti G et al. 2007 - A multiplex PCR-based method for the detection and early identification of wood rotting fungi in standing trees. Journal of Applied Microbiology 103, 1490-1507.

Guglielmo F, Gonthier P, Garbelotto M, Nicolotti G. 2008 - A PCR-based method for the identification of important wood rotting fungal taxa within Ganoderma, Inonotus s.l. and Phellinus s.l. FEMS Microbiology Letters 282, 228-237.

Guglielmo F, Gonthier P, Garbelotto M, Nicolotti G. 2010 - Optimization of sampling procedures for DNA-based diagnosis of wood decay fungi in standing trees. Letters in Applied Microbiology 51, 90-97.

Hansen L, Knudsen H. (eds) 1997 - Nordic Macromycetes, Vol. 3: Heterobasidioid, aphyllophoroid and gastromycetoid Basidiomycetes, 3rd edn. Nordsvamp, Copenhagen.

Hapuarachchi KK, Wen TC, Deng CY, Kang JC et al. 2015 - Mycosphere Essays 1: Taxonomic confusion in the Ganoderma lucidum species complex. Mycosphere 6, 542-559.

Hapuarachchi KK, Wen TC, Jeewon R, Wu XL et al. 2016 - Mycosphere Essays 7: Ganoderma lucidum - are the beneficial anti-cancer properties substantiated? Mycosphere 7, 305-332.

Hapuarachchi KK, Karunarathna SC, Raspé O, De Silva KHWL et al. 2018 - High diversity of Ganoderma and Amauroderma (Ganodermataceae, Polyporales) in Hainan Island, China. Mycosphere 9, 931-982.

Hapuarachchi KK, Karunarathna SC, Phengsintham P, Yang HD et al. 2019 - Ganodermataceae (Polyporales): Diversity in Greater Mekong Subregion countries (China, Laos, Myanmar, Thailand and Vietnam). Mycosphere 10, 221-309.

Hennicke F, Cheikh-Ali Z, Liebisch T, Maciá-Vicente JG et al. 2016 - Distinguishing commercially grown Ganoderma lucidum from Ganoderma lingzhi from Europe and East Asia on the basis of morphology, molecular phylogeny, and triterpenic acid profiles. Phytochemistry 127, 29-37.

Hong SG, Jung HS. 2004 - Phylogenetic analysis of Ganoderma based on nearly complete mitochondrial small-subunit ribosomal DNA sequences. Mycologia 96, 742-755.

Hseu RS, Wang HH, Wang HF, Moncalvo JM. 1996 - Differentiation and grouping of isolates of Ganoderma lucidum complex by random amplified polymorphic DNA-PCR compared with grouping on the basis of internal transcribed spacer sequences. Applied and Environmental Microbiology 62, 1354-1363.

Karsten PA. 1881 - Enumeratio Boletinearum et Polyporearum Fennicarum, systemate novo dispositarum. Revue Mycologique Toulouse 3, 16-19.

Kotlaba F. 1984 - Geographical distribution and ecology of polypores /Polyporales s.l./ in Czechoslovakia. Academia, Praha.

Kotlaba F, Pouzar Z. 2009 - Ecology of Ganoderma resinaceum and its expansion in Bohemia. Mykologické Listy 107, 14-19. 
Kumar S, Stecher G, Tamura K. 2016 - MEGA7: Molecular Evolutionary Genetics Analysis version 7.0 for bigger datasets. Molecular Biology and Evolution 33, 1870-1874.

Leonard AC. 1998 - Two Ganoderma species compared. Mycologist 12, 65-68.

Loyd AL, Richter BS, Jusino MA, Truong C et al. 2018 - Identifying the "Mushroom of Immortality": Assessing the Ganoderma Species Composition in Commercial Reishi Products. Frontiers in Microbiology 9, 1557.

Moncalvo JM, Wang HF, Wang HH, Hseu RS. 1994 - The use of ribosomal DNA sequence data for species identification and phylogeny in the Ganodermataceae. In: Buchanan PK, Hseu RS, Moncalvo JM (eds) Ganoderma: systematics, phytopathology, and pharmacology. International Mycological Congress, Vancouver, 31-44.

Moncalvo JM, Wang HH, Hseu RS. 1995a - Phylogenetic relationships in Ganoderma inferred from the internal transcribed spacers and 25S ribosomal DNA sequences. Mycologia 87, 223238.

Moncalvo JM, Wang HH, Hseu RS. 1995b - Gene phylogeny of the Ganoderma lucidum complex based on ribosomal DNA sequences: Comparison with traditional taxonomic characters. Mycological Research 99, 1489-1499.

Moncalvo JM. 2000 - Systematics of Ganoderma. In: Ganoderma diseases of perennial crops. (Flood J, Bridge PD, Holderness M, eds). CABI Bioscience, Egham, 23-45.

Moncalvo JM, Buchanan PK. 2008 - Molecular evidence for long distance dispersal across the Southern Hemisphere in the Ganoderma applanatum-australe species complex (Basidiomycota). Mycological Research 112, 425-436.

Niemelä T, Miettinen O. 2008 - The identity of Ganoderma applanatum (Basidiomycota). Taxon 57, 963-966.

Nuss I. 1982 - Die bedeutungen der proterosporen: Schlußfolgerungen aus untersuchungen an Ganoderma (Basidiomycetes). Plant Systematic and Evolution 141, 53-80.

Papp V, Szabó I. 2013 - Distribution and Host Preference of Poroid Basidiomycetes in Hungary I. Ganoderma. Acta Silvatica et Lignaria Hungarica 9, 71-83.

Papp V, Dima B, Wasser SP. 2017 - What Is Ganoderma lucidum in the Molecular Era? International Journal of Medicinal Mushrooms 19, 575-593.

Papp V. 2019 - Global Diversity of the Genus Ganoderma. In: Sridhar KR, Deshmukh SK (eds) Advances in Macrofungi. Diversity, Ecology and Biotechnology. CRC Press, Boca Raton, 10-33.

Park YJ, Kwon OC, Son ES, Yoon DE et al. 2012 - Genetic diversity analysis of Ganoderma species and development of a specific marker for identification of medicinal mushroom Ganoderma lucidum. African Journal of Microbiology Research 6, 5417-5425.

Peterson JE. 1987 - Ganoderma in Northern Europe. Mycologist 1, 62-67.

Plank S, Wolkinger F. 1981 - Holzabbauende Pilze an der Waldgrenze im Lachtal (Steiermark, Niedere Tauren). Mitteilungen des Naturwissenschaftlichen Vereines für Steiermark 111, 137-142.

Pristaš P, Gáperová S, Gáper J, Júdová J. 2013 - Genetic variability in Fomes fomentarius reconfirmed by translation elongation factor 1- $\alpha$ DNA sequences and 25S LSU rRNA sequences. Biologia 68, 816-820.

Raja HA, Miller AN, Pearce CJ, Oberlies NH. 2017 - Fungal identification using molecular tools: a primer for the natural products research community. Journal of Nautural Products 80, 756770.

Richter C, Wittstein K, Kirk PM, Stadler M. 2015 - An assessment of the taxonomy and chemotaxonomy of Ganoderma. Fungal Diversity 71, 1-15.

Ryvarden L, Gilbertson RL. 1993 - European polypores. Part 1. Synopsis Fungorum 6, 1-387.

Ryvarden L, Melo I. 2014 - Poroid fungi of Europe. Fungiflora, Oslo.

Schoch CL, Seifert KA, Huhndorf S, Robert V et al. 2012 - Nuclear ribosomal internal transcribed spacer (ITS) region as a universal DNA barcode marker for Fungi. PNAS 109: 6241-6246. 
Schwarze FWMR, Ferner D. 2003 - Ganoderma on trees - differentiation of species and studies of invasiveness. Arboricultural Journal: The International Journal of Urban Forestry 27, 59-77.

Smith BJ, Sivasithamparam K. 2000 - Internal transcribed spacer ribosomal DNA sequence of five species of Ganoderma from Australia. Mycological Research 104, 943-951.

Sokoł S, Kaldorf M, Bothe H. 1999 - Molecular characterization and taxonomic affinities of species of the white rot fungus Ganoderma. Zeitschrift für Naturforschung. C 54, 314-318.

Sokół S. 2000 - Ganodermataceae Polski: Taksonomia, ekologia i rozmieszczenie. Wydawnictwo Uniwersytetu Śląskiego, Katowice.

Steyaert RL. 1972 - Species of Ganoderma and related genera mainly of the Bogor and Leiden herbaria. Persoonia 7, 55-118.

Torres-Torres MB, Dávalos LG. 2012 - The morphology of Ganoderma species with a laccate surface. Mycotaxon 119, 201-216.

Vlasák J. 2015 - Polypores; Collection of Dr. Josef Vlasák, Hluboká nad Vltavou, Czech Republic, edition 18. II. 2015. http://mykoweb.prf.jcu.cz/polypores/ (accessed 08 January 2019).

Wang XC, Xi RJ, Li Y, Wang DM, Yao YJ. 2012 - The Species Identity of the Widely Cultivated Ganoderma, 'G. lucidum' (Ling-zhi), in China. PLOS ONE 7, e40857.

White TJ, Bruns T, Lee S, Taylor J. 1990 - Amplification and direct sequencing of fungal ribosomal RNA genes for phylogenetics. In: Innis GM, Shinsky D, White T (eds) PCR protocols: a guide to methods and applications. Academic, New York, 315-322.

Xing JH, Song J, Decock C, Cui BK. 2016 - Morphological characters and phylogenetic analysis reveal a new species within the Ganoderma lucidum complex from South Africa. Phytotaxa 266, 115-124.

Xing JH, Sun YF, Han YL, Cui BK et al. 2018 - Morphological and molecular identification of two new Ganoderma species on Casuarina equisetifolia from China. MycoKeys 34, 93-108.

Zhou LW, Cao Y, Wu SH, Vlasák J et al. 2015 - Global diversity of the Ganoderma lucidum complex (Ganodermataceae, Polyporales) inferred from morphology and multilocus phylogeny. Phytochemistry 114, 7-15. 